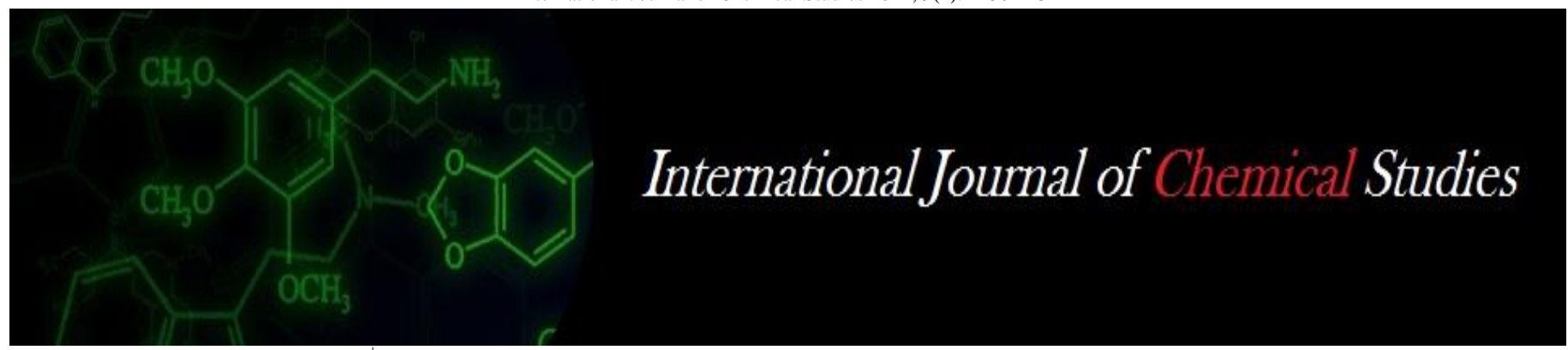

P-ISSN: 2349-8528

E-ISSN: 2321-4902

www.chemijournal.com

IJCS 2021; 9(1): 2130-2134

(C) 2021 IJCS

Received: 02-11-2020

Accepted: 12-12-2020

Naresh Thakur

Department of Crop

Improvement, CSK Himachal

Pradesh Agricultural University,

Palampur, Himachal Pradesh,

India

\section{S Lata}

Department of Crop

Improvement, CSK Himachal

Pradesh Agricultural University,

Palampur, Himachal Pradesh,

India

\section{RK Devlash}

Department of Crop

Improvement, CSK Himachal

Pradesh Agricultural University, Palampur, Himachal Pradesh, India
Corresponding Author:

Naresh Thakur

Department of Crop

Improvement, CSK Himachal

Pradesh Agricultural University,

Palampur, Himachal Pradesh,

India

\section{Evaluation of quality protein maize (QPM) inbred lines and their $f_{1}$ 's under natural epiphytotic and artificial conditions for turcicum leaf blight [(Exserohilum turcicum) (pass.) Leonard and Suggs.]}

\author{
Naresh Thakur, S Lata and RK Devlash
}

DOI: $\underline{\text { htps://doi.org/10.22271/chemi.2021.v9.i1ad.11536 }}$

\begin{abstract}
Maize (Zea mays L.), a staple food crop in many parts of the world, is affected by many diseases that reduce yield varies from 28 to 91 percent. A set was obtained by crossing ten QPM inbred lines in $10 \times 10$ diallel fashion. In total sixty lines including parents, $F_{1}$ 's and standard check (HQPM-1, HQPM-4, HQPM-7, PRATAP QPM-1 and VIVEK QPM-9) were evaluated against leaf blight (Exserohilum turcicum) of maize under field conditions and artificial conditions during kharif 2016 and 2017, respectively. The fourteen cross combination CML163 $\times$ CML161, BAJIMQ-08-26 × CML171, CML180 × BAJIMQ-08-26, CML170 $\times$ CML161, CML189 $\times$ CML162, CML193 $\times$ CML163, CML180 $\times$ CML163, CML180 × BAJIMQ-08-27, CML180 × CML170, BAJIMQ-08-26 × CML189, CML180 $\times$ CML161, CML171 × CML163, CML163 $\times$ CML162 and CML189 $\times$ CML163 and among the parents CML171 exhibited moderately resistance (MR) for Turcicum leaf blight under natural epiphytotic conditions, whereas only five cross combinations CML170 $\times$ CML162, CML193 $\times$ BAJIMQ-08-27, CML180 × CML163, CML189 × CML161, CML180 × CML189 and one parent (BAJIMQ-08-26) showed moderately resistance (MR) for turcicum leaf blight under artificial epiphytotic conditions. These lines identified to possess low disease incidence scores against Turcicum leaf blight in the present study could be used successfully in developing genotypes having a desirable level of resistance in diseaseendemic areas to aim for sustainable productivity.
\end{abstract}

Keywords: Artificial, epiphytotic, maize, natural, turcicum leaf blight

\section{Introduction}

Maize (Zea mays L., 2n=20) belongs to tribe Maydeae, is an important cereal crop of the tropical and sub-tropical regions of the globe and holds an important position in the world's agricultural economy. Maize with a notable productive potential among the cereals, is the third most important grain crop after wheat and rice. At global level maize is cultivated over an area of 197.20 million hectares with an annual production of about 1148.49 million tonnes and average productivity of 5.8 tonnes per hectare (FAOSTAT 2019) ${ }^{[5]}$.

In India, maize contributes to poultry feed (49\%), human food (25\%), animal feed (12\%), industrial use as starch (12\%) beverages and seed (1\%). Maize in India contributes nearly 9 percent in the national food basket (Pingali and Pandey, 2000) ${ }^{[17]}$. However, the demand for maize is expected to touch $45 \mathrm{mt}$ by 2030 of which $24-25$ percent will be used for human consumption, more than 60 percent as poultry and livestock feed and the left over for industrial raw material.

Almost every part of the maize plant is susceptible to numerous diseases that considerably reduce the yield and quality of the crop (Shurtleff, 1980) ${ }^{[21]}$. Though maize is affected by more than 60 diseases, in India about a dozen are of serious concern. Globally, losses due to maize diseases have been estimated to 22.5 percent (Savary et al., 2019) ${ }^{[20]}$. For India, a percent loss of 13.2 has been estimated (Payak and Sharma, 1985) ${ }^{[16]}$. Considering the losses caused by diseases in India, sixteen out of sixty-two diseases have been identified as a major constraint. Maize is one of the most important kharif cereal crops and mainly used as food, feed, and fodder in the state and is grown over a wide range of agro-climatic conditions of 
Himachal Pradesh. Diseases are an important constraint for maize production in the state. Among the various diseases of maize, turcicum leaf blight diseases are usually prevalent in different maize growing areas. Caused by Exserohilum turcicum is an important foliar disease and widespread in all maize growing areas and considered as a limiting factor for the successful cultivation of maize, and results in yield losses from 28 to 91 percent (Pant et al., 2000; Singh et al., 2004) [13, ${ }^{22]}$. The symptoms first start as small elliptical spots on the leaves as greyish green with water-soaked lesions parallel to leaf margins, the spots turn greenish with age and increase in size, finally attaining a spindle shape with long elliptical greyish or tan lesions. If the disease starts at an early stage, it causes premature death of blighted leaves. As a result, the crop loses their nutritive value as fodder (Payak and Renfro, 1968) ${ }^{[14]}$, have reduced germination capacity, vigor, grain yield, and total sugar content, have restricted starch formation, chaffy kernels, and infected plants are liable to infection with stalk rots (Henry and Kettlewell, 1966) ${ }^{[8]}$. The fungus has a wide host range and a high pathogenic variability with several races already reported in different parts of the world (Agrios, 2005) ${ }^{[1]}$. The genetics of resistance is determined in most of the maize genotypes quantitatively and has been used for control of this disease (Sangit et al., 2004) ${ }^{[19]}$. Resistance was partially dominant and controlled by many


maize in plains. Production and productivity of maize in hilly areas are low as compared to the other areas of the country. Keeping the above points in mind, the present study was carried for identification of resistant sources against TLB disease under artificially inoculated and natural epiphytotic conditions which would be useful further in the improvement of maize populations through population improvement programs.

\section{Material and Methods}

The basic materials screened in the present study comprised ten QPM inbred lines. Among ten inbred lines, 8 lines viz., CML161, CML162, CML163, CML170, CML171, CML180, CML189 and CML193 from Indian Institute of Maize Research (IIMR), New Delhi and 2 lines were procured from HAREC Bajaura (Kullu). These lines were crossed in a $10 \times 10$ diallel mating system excluding reciprocals during kharif 2015. The evaluation for TLB under natural condition was done in the main trial at Experimental Farm of the Department of Crop Improvement, College of Agriculture, CSK HPKV, Palampur situated at $1290.8 \mathrm{~m}$ amsl having latitude $32^{\circ} 6^{\prime} \mathrm{N}$ and longitude $76^{\circ} 3^{\prime} \mathrm{E}$ during kharif 2016 and 2017 and for artificial inoculation evaluation work was carried out at the experimental farm of HAREC Bajaura (Kullu) situated at $31^{\circ} 08^{\prime} \mathrm{N}$ latitude and $77^{\circ} \mathrm{E}$ longitude and $1090 \mathrm{~m}$ above mean sea level, representing mid-hill, subhumid zone (Zone 21) of Himachal Pradesh and is endowed with mild summers and cool winters with low monsoon rains $(1036.9 \mathrm{~mm})$ having sandy loam soil. For the screening of material against TLB under the artificial conditions, a separate single row trial in RBD with single replications in a plot size of $2.0 \times 0.60 \mathrm{~m}\left(1.2 \mathrm{~m}^{2}\right)$ at a spacing of $60 \times 20 \mathrm{~cm}$ was conducted during kharif 2016 and 2017. The inoculation was done by dropping a pinch of inoculum by hand inside the whorl of the leaves when the crop was around 35 to 45 days old. This was followed by a spray of water from a knapsack sprayer directed in the whorl. The inoculation was done in the late afternoon. The artificial inoculation was done three times at a weekly interval. Disease reaction of the lines and crosses were recorded for turcicum leaf blight. The data were recorded for leaf blight as per scale used 0-5 (Chenulu and Hora, 1962) ${ }^{[2]}$ Table 1.

Table 1: Scale of disease severity (Chenulu and Hora 1962) ${ }^{[2]}$

\begin{tabular}{|c|c|c|}
\hline Sr. No. & Score & Disease reaction \\
\hline 1. & 0 & Highly resistant \\
\hline 2. & 1 & Resistant \\
\hline 3. & 2 & Moderately resistant \\
\hline 4. & 3 & Moderately susceptible \\
\hline 5. & 4 & Susceptible \\
\hline 6. & 5 & Highly susceptible \\
\hline
\end{tabular}

\section{Result and Discussion}

Disease score of maize genotypes to turcicum leaf blight
(TLB) under natural and artificial inoculation under field conditions during kharif 2016 and 2017 is given in table 2.

Table 2: Disease score of maize genotypes to turcicum leaf blight (TLB) under natural and artificial inoculation under field conditions during kharif 2016 and 2017

\begin{tabular}{|c|c|c|c|c|c|}
\hline \multirow{3}{*}{ Sr. No. } & \multirow{3}{*}{ Genotypes } & \multirow{2}{*}{\multicolumn{2}{|c|}{$\begin{array}{c}\text { TLB (Natural epiphytotic conditions) } \\
\text { Palampur } \\
\end{array}$}} & \multirow{2}{*}{\multicolumn{2}{|c|}{\begin{tabular}{|c|} 
TLB (Artificial inoculation under field conditions) \\
Bajaura
\end{tabular}}} \\
\hline & & & & & \\
\hline & & 2016 & 2017 & 2016 & 2017 \\
\hline 1. & CML162 × CML161 & 3.00 & 3.00 & 4.00 & 4.00 \\
\hline 2. & CML163 × CML161 & 2.00 & 2.00 & 3.00 & 3.00 \\
\hline 3. & CML170 $\times$ CML161 & 2.00 & 2.00 & 3.00 & 3.00 \\
\hline 4. & CML171 × CML161 & 3.00 & 3.00 & 5.00 & 5.00 \\
\hline 5. & CML189 × CML161 & 3.00 & 3.00 & 2.00 & 2.00 \\
\hline 6. & BAJIMQ-08-26 × CML161 & 1.50 & 2.50 & 2.00 & 2.00 \\
\hline 7. & BAJIMQ-08-27 × CML161 & 3.00 & 3.00 & 4.50 & 5.00 \\
\hline 8. & CML193 × CML161 & 2.00 & 2.00 & 2.00 & 2.00 \\
\hline 9. & CML180 × CML161 & 1.50 & 2.50 & 3.00 & 3.00 \\
\hline 10. & CML163 × CML162 & 2.00 & 2.00 & 4.00 & 4.00 \\
\hline 11. & CML170 $\times$ CML162 & 3.00 & 3.00 & 3.00 & 3.00 \\
\hline 12. & CML171 × CML162 & 3.00 & 3.00 & 2.00 & 2.00 \\
\hline 13. & CML189 × CML162 & 2.00 & 2.00 & 3.00 & 3.00 \\
\hline 14. & BAJIMQ-08-26 × CML162 & 3.00 & 3.00 & 3.00 & 3.00 \\
\hline
\end{tabular}




\begin{tabular}{|c|c|c|c|c|c|}
\hline 15. & BAJIMQ-08-27 × CML162 & 3.00 & 3.00 & 5.00 & 5.00 \\
\hline 16. & CML193 × CML162 & 3.00 & 3.00 & 3.00 & 3.00 \\
\hline 17. & CML180 × CML162 & 3.00 & 3.00 & 4.50 & 3.50 \\
\hline 18. & CML170 × CML163 & 3.00 & 3.00 & 3.00 & 3.00 \\
\hline 19. & CML171 × CML163 & 2.00 & 2.00 & 3.00 & 3.00 \\
\hline 20. & CML189 × CML163 & 2.00 & 2.00 & 3.00 & 3.00 \\
\hline 21. & BAJIMQ-08-26 × CML163 & 2.50 & 3.50 & 3.00 & 3.00 \\
\hline 22. & BAJIMQ-08-27 × CML163 & 3.00 & 3.00 & 4.00 & 4.00 \\
\hline 23. & CML193 × CML163 & 2.00 & 2.00 & 3.00 & 3.00 \\
\hline 24. & CML180 × CML163 & 2.00 & 2.00 & 2.00 & 2.00 \\
\hline 25. & CML171 × CML170 & 3.00 & 3.00 & 3.00 & 3.00 \\
\hline 26. & CML189 × CML170 & 3.00 & 3.00 & 4.00 & 4.00 \\
\hline 27. & BAJIMQ-08-26 × CML170 & 3.50 & 2.50 & 5.00 & 5.00 \\
\hline 28. & BAJIMQ-08-27 × CML170 & 3.00 & 3.00 & 3.00 & 3.00 \\
\hline 29. & CML193 × CML170 & 3.00 & 3.00 & 3.00 & 3.00 \\
\hline 30. & CML180 × CML170 & 2.00 & 2.00 & 3.00 & 3.00 \\
\hline 31. & CML189 × CML171 & 3.00 & 3.00 & 3.00 & 3.00 \\
\hline 32. & BAJIMQ-08-26 × CML171 & 2.00 & 2.00 & 4.00 & 4.00 \\
\hline 33. & BAJIMQ-08-27 × CML171 & 2.00 & 2.00 & 2.00 & 2.00 \\
\hline 34. & CML193 × CML171 & 3.00 & 3.00 & 3.00 & 3.00 \\
\hline 35. & CML180 × CML171 & 3.00 & 3.00 & 3.00 & 3.00 \\
\hline 36. & BAJIMQ-08-26 × CML189 & 2.00 & 2.00 & 3.00 & 3.00 \\
\hline 37. & BAJIMQ-08-27 × CML189 & 3.00 & 3.00 & 4.00 & 4.00 \\
\hline 38. & CML193 × CML189 & 3.00 & 3.00 & 3.00 & 3.00 \\
\hline 39. & CML180 × CML189 & 3.00 & 3.00 & 3.00 & 3.00 \\
\hline 40. & BAJIMQ-08-27 × BAJIMQ-08-26 & 3.00 & 3.00 & 3.00 & 3.00 \\
\hline 41. & CML193 × BAJIMQ-08-26 & 2.50 & 3.50 & 3.00 & 3.00 \\
\hline 42. & CML180 × BAJIMQ-08-26 & 2.00 & 2.00 & 3.00 & 3.00 \\
\hline 43. & CML193 × BAJIMQ-08-27 & 3.00 & 3.00 & 2.00 & 2.00 \\
\hline 44. & CML180 × BAJIMQ-08-27 & 2.00 & 2.00 & 3.00 & 3.00 \\
\hline 45. & CML180 × CML193 & 3.00 & 3.00 & 3.00 & 3.00 \\
\hline 46. & HQPM-4 & 3.00 & 3.00 & 3.00 & 3.00 \\
\hline 47. & HQPM-7 & 3.00 & 3.00 & 3.00 & 3.00 \\
\hline 48. & Pratap QPM-1 & 2.00 & 2.00 & 3.50 & 4.50 \\
\hline 49 & CML161 & 3.00 & 3.00 & 4.00 & 4.00 \\
\hline 50. & CML162 & 3.00 & 3.00 & 4.00 & 4.00 \\
\hline 51. & CML163 & 3.00 & 3.00 & 3.00 & 3.00 \\
\hline 52. & CML170 & 3.00 & 3.00 & 4.00 & 4.00 \\
\hline 53. & CML171 & 2.00 & 2.00 & 3.00 & 3.00 \\
\hline 54. & CML189 & 3.00 & 3.00 & 4.00 & 4.00 \\
\hline 55. & BAJIMQ-08-26 & 3.00 & 3.00 & 2.00 & 2.00 \\
\hline 56. & BAJIMQ-08-27 & 3.00 & 3.00 & 4.00 & 4.00 \\
\hline 57. & CML193 & 3.00 & 3.00 & 3.00 & 3.00 \\
\hline 58. & CML180 & 3.00 & 3.00 & 3.00 & 3.00 \\
\hline 59. & HQPM-1 (SC-1) & 1.50 & 2.50 & 4.00 & 4.00 \\
\hline 60. & Vivek QPM-9 (SC-2) & 2.00 & 2.00 & 4.50 & 5.00 \\
\hline
\end{tabular}

Disease reaction under natural epiphytotic conditions during kharif 2016 and 2017

The present study revealed that among the 60 genotypes, nine parents (CML189, BAJIMQ-08-26, BAJIMQ-08-27, CML193, CML180, CML161, CML162, CML163 and CML170), two QPM Check and $31 \mathrm{~F}_{1}$ hybrids viz., CML162 $\times$ CML161, CML170 $\times$ CML162, BAJIMQ-08-26 $\times$ CML163, CML189 × CML171, CML193 × BAJIMQ-08-26, CML171 × CML162, BAJIMQ-08-27 × CML163, BAJIMQ08-27 × CML171, CML193 × BAJIMQ-08-27, CML171 × CML161, BAJIMQ-0826 × CML162, CML193 × CML171, CML189 × CML161, BAJIMQ-08-27 × CML162, CML171 × CML170, CML180 × CML171, CML180 × CML193, BAJIMQ-08-26 × CML161, CML193 × CML162, CML180 $\times$ CML162, BAJIMQ-08-27 $\times$ CML161, BAJIMQ-08-26 $\times$ CML170, BAJIMQ-08-27 × CML189, CML193 × CML161, CML170 × CML163, BAJIMQ-08-27 × CML170, CML193 × CML189, CML193 × CML170, CML180 × CML189, CML180 $\times$ CML170, BAJIMQ-08-27 $\times$ BAJIMQ-08-26 showed the moderately susceptible (MS) reaction. Whereas, one parent (CML171), three QPM Check (PRATAP QPM-1, VIVEK QPM-9, HQPM-1) and 14 cross combination viz., CML163 × CML161, BAJIMQ-08-26 × CML171, CML180 $\times$ BAJIMQ-08-26, CML170 $\times$ CML161, CML189 × CML162, CML193 $\times$ CML163, CML180 $\times$ CML163, CML180 $\times$ BAJIMQ-08-27, CML180 × CML170, BAJIMQ-08-26 $\times$ CML189, CML180 × CML161, CML171 × CML163, CML163 $\times$ CML162 and CML189 $\times$ CML163 exhibited moderately resistance (MR) for Turcicum Leaf Blight (Table 3 ) and none of the genotypes showed the susceptible and highly susceptible reaction against turcicum leaf blight during kharif 2016 and 2017. Similar results were reported by Kumar and Singh (2002) [11], Garg et al. (2007) [6], Kumar and Salgotra (2015) ${ }^{[10]}$ and Thakur et al. (2018) ${ }^{[23]}$. Elliott and Jenkins (1946) screened 200 inbred lines, 126 crosses and 184 double crosses against the Turcicum leaf blight and found that NC34 was the most resistant while CI123, K715, KY114, MO21A, T49B, T105, BK115, CI15 and TX116 showed traces of infection and the resistance to turcicum leaf blight was transmitted to hybrid progeny. 
Table 3: Pooled data of reaction of parents and maize hybrids to turcicum leaf blight during kharif 2016 and 2017 under natural epiphytotic condition

\begin{tabular}{|c|c|c|c|}
\hline Disease score & Reaction & Parents and QPM checks & $F_{1}$ 's \\
\hline 0 & HR & - & - \\
\hline 1 & $\mathrm{R}$ & - & - \\
\hline 2 & MR & $\begin{array}{l}\text { CML171, PRATAP QPM- } \\
\text { 1*, VIVEK QPM-9* } \\
\text { HQPM-1* }\end{array}$ & $\begin{array}{l}\text { CML163×CML161, BAJIMQ-08-26×CML171, CML180×BAJIMQ-08-26, } \\
\text { CML170×CML161, CML189×CML162,CML193×CML163, CML180×CML163, } \\
\text { CML180×BAJIMQ-08-27, CML180×CML170, BAJIMQ-08-26×CML189, } \\
\text { CML180×CML161,CML171×CML163, CML163×CML162 and CML189×CML163 }\end{array}$ \\
\hline 3 & MS & $\begin{array}{c}\text { CML189, BAJIMQ-08-26, } \\
\text { BAJIMQ-08-27, CML193, } \\
\text { CML180, CML161, } \\
\text { CML162, } \\
\text { CML163,CML170,HQPM- } \\
\text { 4*, HQPM-7* }\end{array}$ & $\begin{array}{c}\text { CML162×CML161, CML170×CML162, BAJIMQ-08-26×CML163, } \\
\text { CML189×CML1771, CML193×BAJIMQ-08-26, CML171×CML162, BAJIMQ-08- } \\
\text { 27×CML163, BAJIMQ-08-27×CML171, CML193×BAJIMQ-08-27, } \\
\text { CML171×CML161, BAJIMQ-0826×CML162, CML193×CML171, CML189×CML161, } \\
\text { BAJIMQ-08-27×CML162, CML171×CML170, CML180×CML171, } \\
\text { CML180×CML193,BAJIMQ-08-26×CML161, CML193×CML162, CML180×CML162, } \\
\text { BAJIMQ-08-27×CML161, BAJIMQ-08-26×CML170, BAJIMQ-08-27×CML189, } \\
\text { CML193×CML161, CML170×CML163, BAJIMQ-08-27×CML170, } \\
\text { CML193×CML189, CML193×CML170, CML180×CML189, CML180×CML170, } \\
\text { BAJIMQ-08-27×BAJIMQ-08-26 }\end{array}$ \\
\hline 4 & $S$ & - & - \\
\hline 5 & $\mathrm{HS}$ & & \\
\hline
\end{tabular}

*-indicates checks, HR= Highly Resistant, R= Resistant, MR= Moderately Resistant, MS= Moderately Susceptible, $\mathrm{S}=\mathrm{Susceptible}$, HS= Highly Susceptible

Note: Scale used 0-5 (Chenulu and Hora 1962) ${ }^{[2]}$.

\section{Disease reaction under artificial epiphytotic conditions during kharif 2016 and 2017}

Under artificial epiphytotic conditions only one parent (BAJIMQ-08-26) and five $\mathrm{F}_{1}$ 's viz., CML170 $\times$ CML162, CML193 × BAJIMQ-08-27, CML180 × CML163, CML189 × CML161 and CML180 × CML189 exhibited moderately resistant (MR) reaction. Whereas, four parents (CML193, CML180, CML171, CML163), two QPM checks (HQPM-7, HQPM-4) and twenty five $F_{1}$ 's viz., BAJIMQ-08-26 $\times$ CML163, CML189 × CML171, CML193 × BAJIMQ-08-26, CML163 $\times$ CML161, CML171 $\times$ CML162, CML180 $\times$ BAJIMQ-08-26, CML170 × CML161, CML189 × CML162, CML193 $\times$ CML163, BAJIMQ-0-27 × CML171, BAJIMQ08-26 $\times$ CML162, CML193 $\times$ CML171, CML180 $\times$ BAJIMQ-08-27, CML171 $\times$ CML170, BAJIMQ-08-26 $\times$ CML161, CML193 × CML162, CML193 × CML161, CML170 × CML163, BAJIMQ-08-27 × CML170, CML193 ×
CML189, CML180 × CML161, CML171 × CML163, CML193 $\times$ CML170, CML189 $\times$ CML163 and CML180 $\times$ CML170 showed the moderately susceptible (MS) reaction. Five parents (CML162, CML170, CML189, BAJIMQ-08-27, CML161), two QPM checks (PRATAP QPM-1, HQPM-1) and nine $\mathrm{F}_{1}$ 's viz, CML163 $\times$ CML162, BAJIMQ-08-27 $\times$ CML189, CML162 × CML161, BAJIMQ-08-27 × CML163, BAJIMQ-08-26 × CML171, CML193 $\times$ BAJIMQ-08-27, CML189 $\times$ CML170, BAJIMQ-08-26 $\times$ CML189 and CML180 $\times$ CML162 exhibited susceptible (S) reaction. Whereas, one QPM check (VIVEK QPM-9) and six F $_{1}$ 's viz., BAJIMQ-08-27 $\times$ BAJIMQ-08-26, BAJIMQ-08-26 $\times$ CML170, BAJIMQ-08-27 × CML161, CML180 × CML171, BAJIMQ-08-27 $\times$ CML162 and CML171 $\times$ CML161 (Table 4) showed the highly susceptible (HS) reaction for turcicum leaf blight.

Table 4: Reaction of parents and maize hybrids to turcicum leaf blight during kharif 2016 and 2017 under artificial epiphytotic condition

\begin{tabular}{|c|c|c|c|}
\hline Disease score & Reaction & Parents and QPM checks & $F_{1}$ 's \\
\hline 0 & HR & - & - \\
\hline 1 & $\mathrm{R}$ & - & - \\
\hline 2 & MR & BAJIMQ-08-26 & $\begin{array}{l}\text { CML170×CML162, CML193×BAJIMQ-08-27, CML180×CML163, } \\
\text { CML189×CML161, CML180×CML189 }\end{array}$ \\
\hline 3 & MS & $\begin{array}{c}\text { CML193, CML180, CML171, } \\
\text { CML163, HQPM-7*, HQPM- } \\
4^{*}\end{array}$ & \begin{tabular}{|c|} 
BAJIMQ-08-26×CML163, CML189×CML171, CML193×BAJIMQ-08-26, \\
CML163×CML161, CML171×CML162, CML180×BAJIMQ-08-26, \\
CML170×CML161, CML189×CML162, CML193×CML163, BAJIMQ-0- \\
27×CML171, BAJIMQ-08-26×CML162, CML193×CML171, CML180×BAJIMQ-08- \\
27, CML171×CML170, BAJMQ-08-26×CML161, CML193×CML162, \\
CML193×CML161, CML170×CML163, BAJIMQ-08-27×CML170, \\
CML193×CML189, CML180×CML161, CML171×CML163, CML193×CML170, \\
CML189×CML163, CML180×CML170
\end{tabular} \\
\hline 4 & S & \begin{tabular}{|c|} 
CML162, CML170, CML189, \\
BAJIMQ-08-27, CML161, \\
HQPM-1*, PARTAP QPM-1*
\end{tabular} & $\begin{array}{l}\text { CML163×CML162, BAJIMQ-08-27×CML189, CML162×CML161, BAJIMQ- } \\
\text { 08027×CML163, BAJIMQ-08-26×CML171, CML193×BAJIMQ-08-27, } \\
\text { CML189×CML170, BAJIMQ-08-26×CML189, CML180×CML162 }\end{array}$ \\
\hline 5 & HS & VIVEK QPM-9* & $\begin{array}{l}\text { BAJIMQ-08-27×BAJIMQ-08-26, BAJIMQ-08-26×CML170, BAJIMQ-08- } \\
\text { 27×CML161, CML180×CML171, BAJIMQ-08-27×CML162, CML171×CML161 }\end{array}$ \\
\hline
\end{tabular}

*-indicates checks, HR= Highly Resistant, R= Resistant, MR= Moderately Resistant, MS= Moderately Susceptible, S= Susceptible, HS= Highly Susceptible

Note: Scale used 0-5 (Chenulu and Hora 1962) ${ }^{[2]}$.

Disease reaction indicating a satisfactory level of disease development and the categorization of genotypes into different classes were appropriate (Table 3 and Table 4). The results are in accordance with Ramdutta and Lal (2005) ${ }^{[18]}$ 
who screened maize genotypes under artificial epiphytotic conditions. These findings were in agreement with results obtained by Dharanendra (2003) [3], Ishfaq et al. (2014) [9], Mir et al. (2015) [12], Gulzar et al. (2018) [7], Thakur et al. (2018) ${ }^{[23]}$ and Wani et al. (2018) ${ }^{[25]}$. The resistant sources with varying levels of resistance do exist against the Turcicum leaf blight disease of maize. The determination of the genetic basis of the resources and incorporation of their significant difference was observed in disease ratings among the genotypes under field and controlled conditions. The effect of the disease was more severe in the green house plants. The differences attributed due to several factors including controlled environmental conditions, host genotype, inoculation methods and resistance variation among the genotypes.

Continuous efforts to locate resistant source and utilization in resistant breeding programs are imperative to manage the disease in the long run. Some genotypes possess low disease incidence scores against turcicum leaf blight (TLB) in the present study could be used successfully in developing genotypes having the desired level of resistance in diseaseendemic areas to aim for sustainable productivity. The lines identified to possess less proneness to turcicum leaf blight in the present study can be used successfully in developing high yielding early maturing varieties for the hill region having a high level of resistance to turcicum leaf blight. However resistance and susceptibility to the disease may be attributed to anatomical structures of studied genotypes, however, it needs further investigations.

\section{References}

1. Agrios GN. Plant pathology ( $5^{\text {th }}$ edition). Academic Press, Burlington 2005.

2. Chenulu W, Hora TS. Studies on losses due to Helminthosporium blight of maize. Indian Phytopath 1962;15:235-237.

3. Dharanendra S. Studies on turcicum leaf blight of maize caused by Exserohilum turcicum. M.Sc. Thesis, University of Agricultural Science Dharwad, Karnatka, India 2003.

4. Elliott C, Jenkins MT. Helminthosporium turcicum leaf blight of corn. Phytopathology 1946;36:660-666.

5. FAO STAT. STAT of Food and Agriculture 2019, P99.

6. Garg A, Prassana BM, Sharma RC, Rathore RS, Saxena SC, Chauhan SVS. Identification of resistance source to banded leaf and sheath blight (Rhizoctonia solani $\mathrm{F}$. sp sasakii) in maize. Indian Phytopath 2007;60:162-166.

7. Gulzar S, Dar ZA, Ahangar MA, Lone AA, Bhat MA, Kamal-ud-din, Khan MA, Sofi PA, Yousuf V, Yousuf N, Majid A. Identification of reaction pattern to turcicum leaf blight among early maturing maize (Zea mays L.) inbred lines. J Pharmaco. Phytochem 2018;7:1657-1660.

8. Henry RJ, Kettlewell PS. Cereal grain quality. Chapman and Hall 1966.

9. Ishfaq A, Dar ZA, Lone AA, Ali G, Gazal A, Hamid B, Mohiddin FA. Disease reaction studies of maize (Zea mays L.) against turcicum leaf blight involving indigenously identified cytosterile source. Afr. J Microbiol. Res 2014;8:2592-2597.

10. Kumar J, Salgotra SK. Evaluation of maize hybrids against leaf blight (Helminthosporium maydis and Helminthosporium turcicum) and brown spot diseases (Physoderma zea maydis) of maize under mid hills of North Western Himalayas. Maize Genom. Genet 2015;6:1-5.
11. Kumar R, Singh IS. Inheritance of resistance to banded leaf and sheath blight (Rhizoctonia solani F. sp sasakii) of maize (Zea mays L), Proceedings of the $8^{\text {th }}$ Asian Regional Maize Workshop, Bangkok, Thailand 2002;356-365.

12. Mir SD, Ahmad M, Parray GA, Razvi SM, Gul-Zaffar. Screening of maize inbred lines under artificial epiphytotic conditions for turcicum leaf blight (Exserohilum turcicum). Afr. J Microbiol. Res 2015;9:481-483.

13. Pant SK, Kumar P, Chauhan VS. Effect of turcicum leaf blight on photosynthesis in maize. Indian Phytopath 2000;54:251-252.

14. Payak MM, Renfro BL. Combating maize disease. Indian Farmer Digest 1968;1:53-58.

15. Payak MM, Sharma RC. Maize diseases and approaches to their management in India. Trop. Pest Manag 1985;31:302-310.

16. Payak MM, Sharma RC. An inventory and bibliography for maize diseases in India. Division of Mycology and Plant Pathology, IARI, New Delhi 1980, P67.

17. Pingali PL, Pandey S. Meeting world maize needs: technological opportunities and priorities for the public sector. World Maize Facts and Trends 2000.

18. Ramdutta MS, Lal S. Evaluation of maize genotypes for locating sources of resistance to Exserohilum turcicum incitant of turcicum leaf blight of maize. Indian Phytopath 2005;58:67-70.

19. Sangit K, Pardurange GKT, Pant SK, Meena S, Bhupesh K, Bineet K, Hettiara CK, Ferugson LM, Carson ML. Spatial diversity of Setosphaeria turcica sampled from the eastern United States. Phytopathology 2004;94:992900.

20. Savary S, Willocquet L, Pethybridge SJ, Esker P, McRoberts N, Nelson A. The global burden of pathogens and pests on major food crops. Nature Ecol. Evol 2019;3:430-439.

21. Shurtleff MC. Compendium of corn disease. 2nd Edn. American Phytopathology Society 1980, P105.

22. Singh R, Manin VP, Koranga KS, Khendelwal RS, Bhandari NP, Pant SK. Identification of additional sources of resistance to Exserohilum turcicum in maize (Zea mays L.). SABRAO J Breed. Genet 2004;36:45-47.

23. Thakur S, Guleria SK, Devlash R. Screening for resistance against turcicum leaf blight under natural and artificial epiphytotic conditions in maize (Zea mays L.). Annals Plant Soil Res 2018;20:52-57.

24. Vanderplank JE. Plant disease epidemics and control. Academic press, New York 1963, P349.

25. Wani TA, Bhat GN, Ahmad M, Anwar A, Zaffar G. Screening of maize germplasm for Turcicum leaf blight resistance. J Appl. Nature Sci 2018;10:98-101. 